\title{
Introducing Perovskite Solar Cells to Undergraduates
}

T $\mathrm{n}$ this Viewpoint, we show that it is sufficiently easy and cheap to fabricate a perovskite solar cell that this can be done as an undergraduate laboratory experiment. Solar cells, which have been around since the 1950s, are considered as a prominent source of renewable energy in the future. ${ }^{1}$ Conventional solar cells, which are used in rooftop applications, are based on single-crystal silicon and are up to $25 \%$ efficient. $^{2,3}$ Considerably more expensive solar cells based on GaAs (gallium arsenide) single crystals are $\sim 29$ and over $40 \%$ efficient in single- and multijunction devices, respectively. ${ }^{2}$ They are used on satellites and in other space applications. Over the past 2 decades, solar cells based on thin-film polycrystalline materials, especially $\mathrm{CdTe}$ (cadmium telluride) and CIGS (copper indium gallium selenide), have emerged as a viable alternative to silicon cells with efficiencies exceeding $20 \%{ }^{2}$ A new arrival in this family is organic-inorganic halide perovskites. ${ }^{4,5}$ First introduced in 2012, the efficiency of these cells has risen from 10 to $20 \%$ in just 2 years. $^{6-10}$ This is to be compared to the mainstream of emerging photovoltaic technologies, such as polymer cells, ${ }^{11}$ dye-sensitized solar cells (DSSCs), ${ }^{12}$ and quantum dot solar cells, ${ }^{13}$ which are $8-$ $13 \%$ efficient after 2 decades of research.

The sudden emergence of perovskite solar cells and their facile solution-based fabrication method offer a unique opportunity to give chemistry students hands-on experience in mainstream photovoltaics. Currently, only a few solar cell fabrication experiments, primarily DSSCs, are accessible to chemistry students. ${ }^{14-16}$ The laboratory experiment described here leads to fabrication of methylammonium lead triiodide $\left(\mathrm{MAPbI}_{3}\right)$ perovskite solar cells using a simple step-by-step deposition procedure, followed by measurements with routine equipment. The cost of fabricating one cell is below 20 cents, and it takes $2-5 \mathrm{~h}$. The experiment is suitable for chemistry students to learn about thin-film polycrystalline solar cells, energy conversion, materials and methods, chemical reactivity, stoichiometry, and the optical and electronic properties of materials. A YouTube video of the experiment, which is highly appropriate for a classroom demonstration, is available at: https://www.youtube.com/watch?v=RqW9HrasNPA.

Procedure. The solar cell device consists of layers of titania $\left(\mathrm{TiO}_{2}\right)$, perovskite $\left(\mathrm{CH}_{3} \mathrm{NH}_{3} \mathrm{PbI}_{3}\right)$, copper thiocyanate $(\mathrm{CuSCN})$, and carbon particles, sandwiched between two glass plates. A physical model of the device is shown in Figure 1 , which is useful to teach solar cell fabrication in classrooms. The fabrication steps are depicted in Figure 2 with detailed description provided below.

Step 1. Take a piece of FTO glass $(2 \mathrm{~cm} \times 1.4 \mathrm{~cm})$, which is a piece of glass coated with transparent and conductive material, fluorine-doped tin oxide (FTO), on one side. Determine the conducting side using a multimeter. To do this, set the multimeter to resistance mode $(200 \Omega)$, plug the two leads into the multimeter, and measure the sheet resistance on the two sides using the probes (Figure 3). The conducting side will give low resistance (tens of ohms), while the uncoated side will not give any value. Notice that the FTO side has more

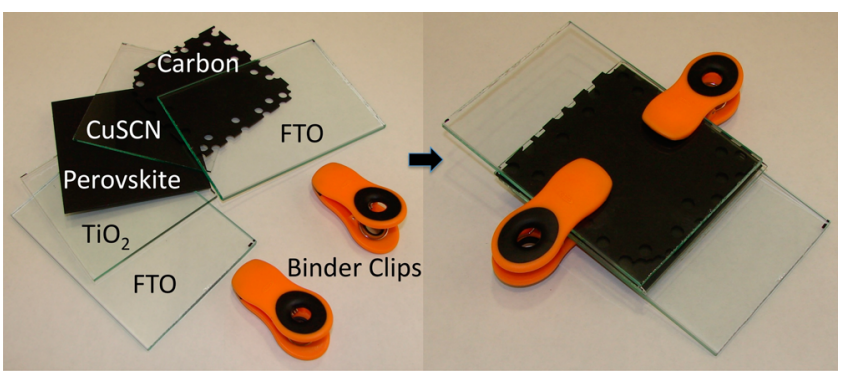

Figure 1. A physical model that is appropriate to teach the design and fabrication of perovskite solar cell in classrooms.

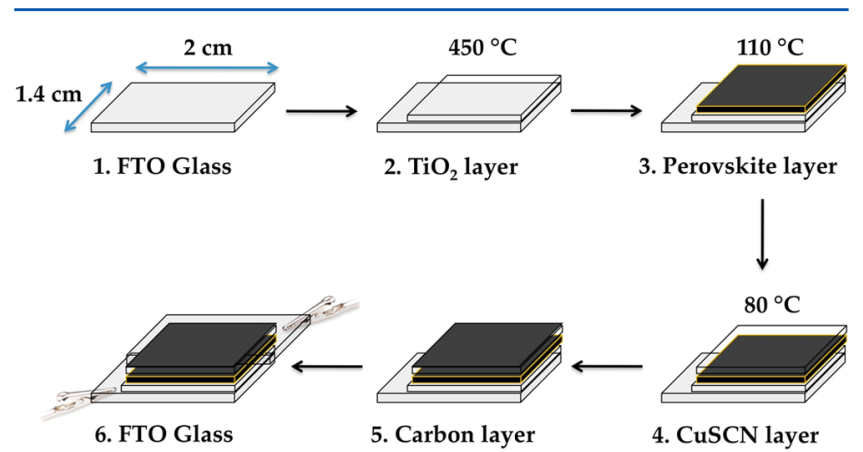

Figure 2. Fabrication procedure for perovskite solar cells.

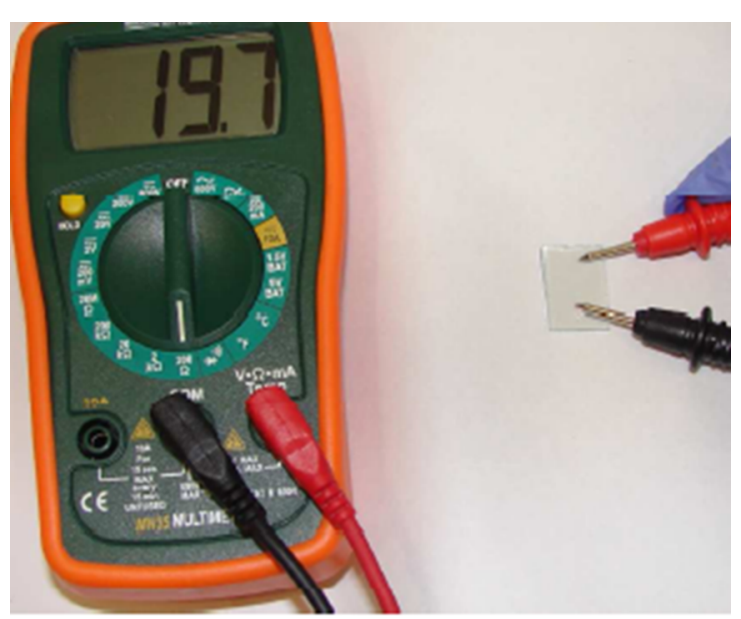

Figure 3. Measurement of sheet resistance using a multimeter.

friction compared to the uncoated one when moving the probe over it.

Step 2. Place the FTO glass plate on the benchtop with the conductive side facing up. Tape the glass plate to the benchtop with scotch tape covering $1 / 4$ of the surface, as shown in Figure 4. Put one drop of $\mathrm{TiO}_{2}$ precursor solution ${ }^{17}(0.2 \mathrm{M}$ titanium isopropoxide $+0.1 \mathrm{M} \mathrm{HCl}$ in anhydrous ethanol) and spread it across the surface with a pipet. Roll it over the surface several

Published: January 15, 2015 


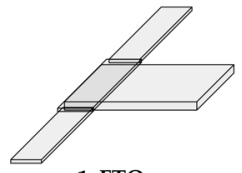

1. FTO

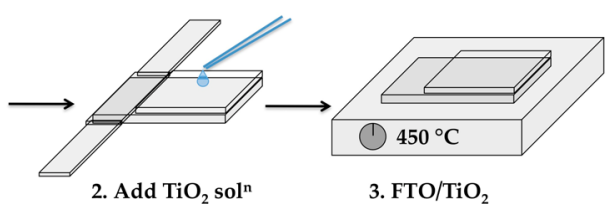

2. Add $\mathrm{TiO}_{2}$ sol $^{\mathrm{n}}$

3. $\mathrm{FTO} / \mathrm{TiO}_{2}$
Figure 4. Procedure to deposit a $\mathrm{TiO}_{2}$ layer on a FTO glass plate, covering $3 / 4$ of its surface.

times to obtain a uniform smooth thin film. Remove the tape entirely and place the glass plate on a hot plate. Turn the heat on and put it at $450{ }^{\circ} \mathrm{C}$. After $20 \mathrm{~min}$, turn off the heat and wait for $10 \mathrm{~min}$. Remove the plate from the hot plate with tweezers and wait for $5 \mathrm{~min}$ to bring the plate to ambient temperature.

Step 3. Place the glass plate on the benchtop with the FTO/ $\mathrm{TiO}_{2}$ side facing up. Put heat-resistant tape on the glass plate covering the bare FTO surface, as shown in Figure 5. Put one

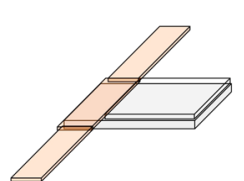

1. $\mathrm{FTO} / \mathrm{TiO}_{2}$
2. Add Perovskite sol ${ }^{\mathrm{n}} \quad$ 3. $\mathrm{FTO} / \mathrm{TiO}_{2} /$ Perovskite

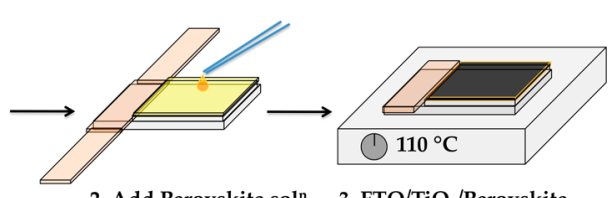

Figure 5. Procedure to deposit perovskite $\left(\mathrm{CH}_{3} \mathrm{NH}_{3} \mathrm{PbI}_{3}\right)$ on a FTO/ $\mathrm{TiO}_{2}$ film. In 3, 1/4 of the FTO surface is covered with heat-resistant tape, and $3 / 4$ of the FTO surface is covered with $\mathrm{TiO}_{2} /$ perovskite.

drop of perovskite precursor solution ${ }^{18}$ (0.5 M lead chloride + $1.5 \mathrm{M}$ methylammonium iodide in DMF) on the $\mathrm{FTO} / \mathrm{TiO}_{2}$ film and spread it across the surface with a pipet. Roll it over the surface a few times to obtain a uniform smooth thin film. Remove the excess tape with a razor-blade, keeping the tape covering the glass plate intact. Put the glass plate on the hot plate preheated to a temperature in the $90-120^{\circ} \mathrm{C}$ range. After the film turns black, wait for at least $10 \mathrm{~min}$ before proceeding to Step 4.

Step 4. Turn the temperature of the hot plate down to $80{ }^{\circ} \mathrm{C}$. Put one drop of CuSCN solution ${ }^{19-21}$ (0.05 M CuSCN in dipropyl sulfide) and spread it across the surface with a pipet. Roll it over the surface a few times to obtain a uniform smooth thin film. Wait for $15 \mathrm{~min}$ and remove the glass plate from the hot plate (Figure 6).

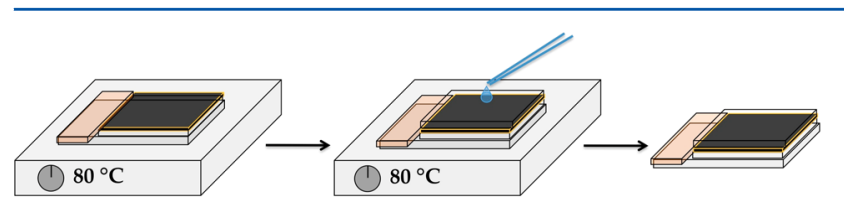

1. $\mathrm{FTO} / \mathrm{TiO}_{2} /$ Perovskite

2. Add CuSCN soln $\quad$ 3. FTO/TiO $/$ Perovskite/CuSCN

Figure 6. Procedure to deposit $\mathrm{CuSCN}$ on $\mathrm{FTO} / \mathrm{TiO}_{2} /$ perovskite film. In 3, 1/4 of the FTO surface is covered with heat-resistant tape, and $3 / 4$ of the FTO surface is covered with $\mathrm{TiO}_{2} /$ perovskite/CuSCN.

Step 5. Put a small amount of carbon particles on the $\mathrm{CuSCN}$ film and place another FTO glass plate over it with the conductive side facing down (Figure 7). Spread the carbon particles over the surface by pressing and sliding the two plates against each other. It is difficult to obtain a smooth film of carbon particles because the particles do not stick to the FTO plate and $\mathrm{CuSCN}$ surfaces. However, it is more important to avoid damaging the $\mathrm{FTO} / \mathrm{TiO}_{2} /$ perovskite/CuSCN film than to obtain a uniform film of carbon particles over it. The two

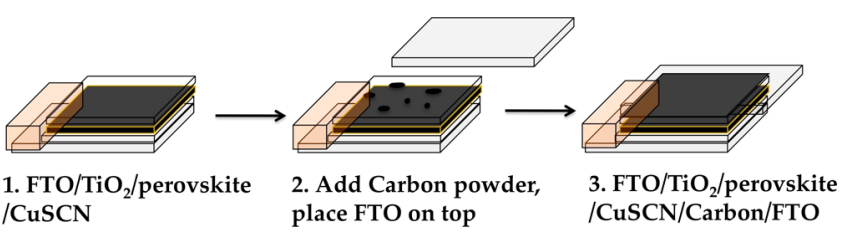

Figure 7. Procedure to deposit a carbon layer on the $\mathrm{FTO} / \mathrm{TiO}_{2} /$ perovskite/CuSCN film. In 3, 1/4 of the bottom FTO plate is covered with heat-resistant tape, while $3 / 4$ of the surface is covered with $\mathrm{TiO}_{2}$ / perovskite/CuSCN/carbon with another FTO plate on top.



Figure 8. Measurement of the photovoltage under sunlight and in dark conditions. The device is kept in the palm of one hand, controlling the exposure to sunlight with the other.

FTO plates should be laterally shifted to make good electrical contacts and avoid a short circuit. Use two binder clips to keep the FTO plates in place (Figure 8). Now, remove the heatresistant tape to expose the FTO surface.

Electrical Characterization. Connect two leads to the multimeter and two alligator clips to the FTO plates (Figure $8)$. Now, connect the other ends of the alligator clips to the probes of the leads. Measure the voltage by turning the multimeter range knob to the $2 \mathrm{~V}$ mark and the current by turning the multimeter range knob to the $1 \mathrm{~mA}$ mark. As a light source, use LED (light-emitting diode) torches of different intensities or sunlight (if available and accessible).

Learning Objectives. Through this experiment, students get to apply the concepts of conduction band (CB), valence band (VB), band gap, and charge-transport properties of semiconductors to understand the solar cell operation (Figure 9). Without defining these terms further, we will use them in the following discussion to understand how a unique combination of different materials leads to an operational solar cell device.

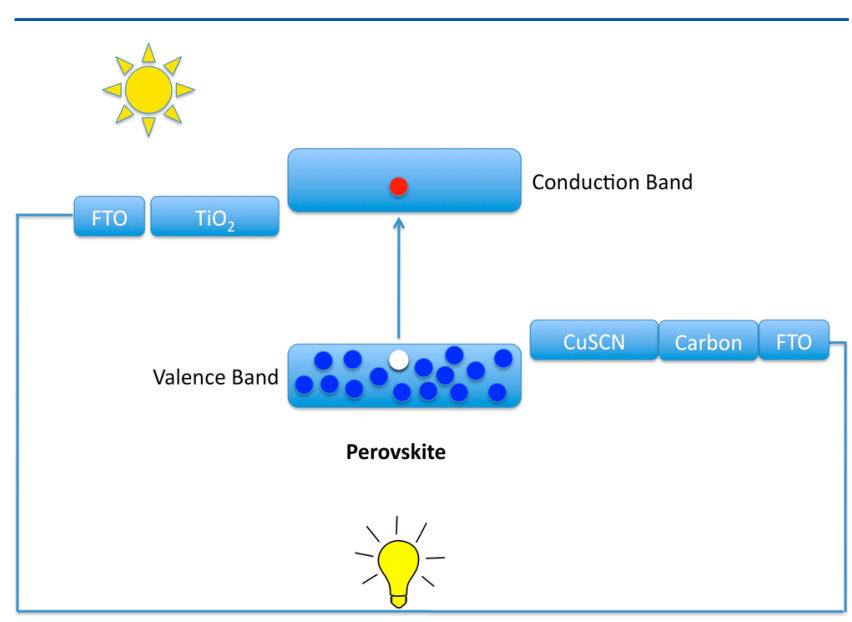

Figure 9. Figure depicting solar cell operation: from light absorption to electrical power generation. 
To teach some of the content in classrooms, the use of a solar cell model (Figure 1) is highly appropriate.

The perovskite layer, with a band gap of $\sim 1.5 \mathrm{eV}$, absorbs light and creates electrons in the $\mathrm{CB}$ and holes in the VB (Figure 9). ${ }^{22}$ The $\mathrm{TiO}_{2}$ and $\mathrm{CuSCN}$ layers do not absorb visible light due to their wide band gap, but they exhibit significantly faster electron and hole transport, respectively. $\mathrm{TiO}_{2}$, with its $\mathrm{CB}$ below the $\mathrm{CB}$ of perovskite, selectively transfers electrons from the perovskite's $\mathrm{CB}$ to the FTO anode. $^{23}$ Similarly, CuSCN, with its VB above the VB of perovskite, selectively transfers holes through the carbon particles to the FTO cathode. ${ }^{20,21}$ With electrons on the anode and holes on the cathode, the solar cell can power an external device, such as a LED.

From measurements of current and voltage under dark and illumination, students learn about solar energy to electrical energy conversion. If the materials from nonadjacent layers of the device come into physical contact (see Figure 1), for example, due to the presence of a scratch, the device may get short-circuited, that is, electrons and holes on the device recombine internally, leading to negligible voltage and current. $^{20}$ The solar cell devices described here give an opencircuit voltage up to $500 \mathrm{mV}$. Considering the band gap of 1.5 $\mathrm{eV}$, this represents a loss of $1 \mathrm{~V}$. Research-grade cells using the same material can achieve up to $1.1 \mathrm{~V}$, with loss of just $400 \mathrm{mV}$. Similarly, short-circuit currents up to $2-3 \mathrm{~mA}$ can be achieved in our devices, compared to well over $10 \mathrm{~mA}$ in research-grade cells (assuming an active area of $\sim 0.7 \mathrm{~cm}^{2}$ in both). The major loss in current occurs because the films are too thick to get the charges across $^{24,25}$ as well as due to internal recombination of charge carriers. From the open-circuit voltage and short-circuit current, the power conversion efficiencies can be calculated. Assuming an active surface area of $0.7 \mathrm{~cm}^{2}$, a $70 \%$ fill factor, and $100 \mathrm{~mW} / \mathrm{cm}^{2}$ solar radiation, a measured voltage of $100 \mathrm{mV}$ and a current of $1 \mathrm{~mA}$ result in a $0.1 \%$ efficient solar cell. Another interesting observation is that the photovoltage increases over time with a constant solar irradiation. Moreover, if LED torches of different intensities are used, the higherintensity light produces a higher voltage. The same effect can be achieved by bringing the torch closer to the solar cell. A bandfilling model can qualitatively explain this observation, ${ }^{26}$ where upon optical absorption electrons from the top of the VB fill the bottom of the $\mathrm{CB}$ first. As these energy levels become unavailable, the effective band gap for the remaining electrons becomes higher, resulting in increased photovoltage either at constant light intensity over time (several seconds) or with increasing light intensity. The concept of concentrated photovoltaics can be understood from this exercise, where usually a very expensive but highly stable multijunction solar cell is irradiated with concentrated sunlight equivalent to 1001000 suns to produce a lot of power. The efficiency of these solar cells is higher at higher light intensities. ${ }^{27}$

The key chemical concepts behind the solution deposition method include solubility, chemical reactivity, and stoichiometry. For deposition of the $\mathrm{TiO}_{2}$ layer (Step 2), we use a precursor solution containing titanium isopropoxide. As we heat the drop-casted film on FTO at $450{ }^{\circ} \mathrm{C}$, the titanium atoms form stable chemical bonds with the surface atoms of FTO while the other components in the solution evaporate or burn out. The atmosphere provides a source of oxygen for oxidation. After annealing for some time, we obtain a thin film of $\mathrm{TiO}_{2}$. The deposition of $\mathrm{CuSCN}$ from the dipropyl sulfide solvent (Step 4) is easiest to understand from a chemical reactivity standpoint. Here, the solvent evaporates, leaving behind crystallites of the sparingly soluble $\mathrm{CuSCN}$ on the $\mathrm{FTO} / \mathrm{TiO}_{2} /$ perovskite film.

The chemistry of the perovskite deposition (Step 3) is most interesting. Perovskite, named after a Russian mineralogist Lev Perovski, is cubic $\mathrm{ABX}_{3}$ material consisting of corner-sharing octahedral $\left(\mathrm{BX}_{6}\right)$ with the A-cation occupying a 12-fold coordination site (Figure 10). In $\mathrm{CH}_{3} \mathrm{NH}_{3} \mathrm{PbI}_{3}$ perovskite, A
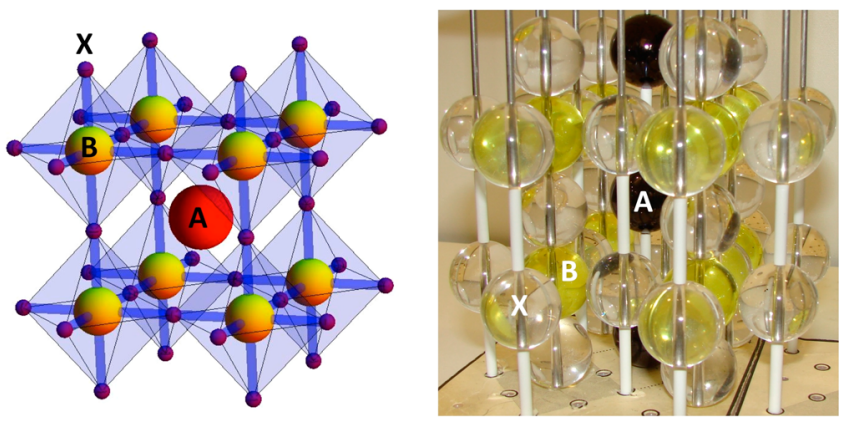

Figure 10. Ideal cubic structure of perovskite, with the general formula $\mathrm{ABX}_{3}$, consisting of corner-sharing octahedra $\left(\mathrm{BX}_{6}\right)$ with the A-cation occupying a 12 -fold coordination site. The crystal structures were built by a computer program and crystal structure building kit.

is a monovalent cation $\mathrm{CH}_{3} \mathrm{NH}_{3}{ }^{+}, \mathrm{B}$ is a divalent cation $\mathrm{Pb}^{2+}$, and $\mathrm{X}$ is a monovalent halide anion $\mathrm{I}^{-}$. To deposit this material from solution, a 1:3 molar solution of $\mathrm{PbCl}_{2}$ and $\mathrm{CH}_{3} \mathrm{NH}_{3} \mathrm{I}$ in DMF is prepared. This molar ratio reflects the ratio for lead and iodide (1:3) in the final material, that is, $\mathrm{CH}_{3} \mathrm{NH}_{3} \mathrm{PbI}_{3}$. The $\mathrm{PbCl}_{2}$ and $\mathrm{CH}_{3} \mathrm{NH}_{3} \mathrm{I}$ are both white powders, indicating wideband-gap materials. Interestingly, after mixing the two in DMF, the resulting solution is yellow, which is attributed to the formation of $\mathrm{PbI}_{x}$ clusters in solution ${ }^{28}$ (note that $\mathrm{PbI}_{2}$ powder is yellow). As we deposit this precursor solution and anneal it at $\sim 110{ }^{\circ} \mathrm{C}$, the solvent evaporates, and $\mathrm{PbI}_{x}$ clusters assemble with the $\mathrm{CH}_{3} \mathrm{NH}_{3}$ cations to form the stable $\mathrm{CH}_{3} \mathrm{NH}_{3} \mathrm{PbI}_{3}$ perovskite structure, which is black in color. The role of chloride ions is to assist in the effective assembly of components to form $\mathrm{CH}_{3} \mathrm{NH}_{3} \mathrm{PbI}_{3}$ crystallites. Because of its substantially different ionic radius, the chloride ions cannot substitute for iodine ions in the perovskite, and they are absent from the bulk perovskite crystal that results from such a reaction mixture. ${ }^{29}$ Because students can visually observe the color change from white to yellow to black, they naturally understand the underlying chemical reactivity of the solution deposition technique. Regarding the stability of the final material, it is interesting to note that grinding the $\mathrm{PbI}_{2}$ and $\mathrm{CH}_{3} \mathrm{NH}_{3} \mathrm{I}$ powders directly, ${ }^{30}$ without a solvent, also forms black perovskite powder, indicating its stability over individual components.

Implementation. This experiment can be introduced as a 3-5 $\mathrm{h}$ activity. For shorter sessions $(\sim 2 \mathrm{~h})$, the $\mathrm{TiO}_{2}$-coated FTO films can be prepared beforehand, and students can start the experiment from Step 3. The three solutions have to be prepared fresh for the experiment. Usually, if the solution vials are sealed by paraffin paper and kept in the dark under ambient conditions, the perovskite and $\mathrm{TiO}_{2}$ solutions last for at least 2 weeks, while $\mathrm{CuSCN}$ solution is good for months.

The common bottleneck of introducing new laboratory experiments is a limited know-how about new materials and methods and the cost associated with it. To overcome the latter, we have provided cost analysis for this experiment and 
the source of all chemicals used in the Supporting Information. The estimated cost per solar cell is below 20 cents, provided that standard laboratory equipment is used.

The solar cells fabricated using standard laboratory equipment suffer from poor reproducibility due to limited control over film thickness and morphology. Ideally, thin and uniformly covered films are required, which is hard to achieve by the drop-casting method described above. A spin-coater, which uses a spinning stage for the substrate, could be used to remove excess solution from the film and obtain the desired film qualities, reproducibly.

The quality of the perovskite film and, therefore, the solar cell performance are highly sensitive to annealing temperature. ${ }^{19}$ The standard hot plates with induction heating either do not have a temperature meter or it is not properly calibrated. Moreover, the temperature of the hot plate varies from the center of the plate to the edges. In this case, the perovskite deposition step relies on visual observation (formation of blackcolored perovskite) with only a rough estimate for the temperature available. To improve the reproducibility in observed current/voltage, well-calibrated hot plates with uniform surface temperature profiles could be used.

Overall, perovskite solar cells offer great variability. A combination of different electron/hole-transporting materials and light-absorbing perovskites could be used to fabricate solar cells. ${ }^{3,32}$ Instead of using planar device structure, an additional layer of mesoporous $\mathrm{TiO}_{2}$ or $\mathrm{Al}_{2} \mathrm{O}_{3}$ on $\mathrm{FTO} / \mathrm{TiO}_{2}$ could be used to fabricate perovskite cells. ${ }^{7}$ Different solution deposition techniques could be used to obtain the perovskite film. ${ }^{5}$ In this work, we used simple device architecture and a combination of inexpensive materials to demonstrate the feasibility of translating this state of the art technology into an undergraduate laboratory, and indeed, we have already used it for advanced General Chemistry students. We anticipate that a combination of materials and methods will be available in the near future to allow fabrication of high-efficiency cells in an undergraduate laboratory setting. Subsequently, in a more multidisciplinary experiment, students will be able to create solar panels from these high-efficiency cells and drive electronic devices, such as electrical motors and LEDs. We are working toward realizing this goal in the near future.

Safety Note. Like any other chemistry experiment, it is important that students are aware of the chemical hazards and the proper ways to handle them. It is necessary to consult the Material Safety Data Sheet (MSDS) beforehand. The majority of the chemicals used in this experiment are safe with proper supportive Personal Protective Equipment (PPE). The perovskite solution has lead, which is known to be toxic to organs and tissues and have interferences with many various body processes. ${ }^{33}$ However, the amount of lead required to fabricate one device in this experiment is very low, specifically $2.8 \mathrm{mg} /$ device. In case of skin contact, wash thoroughly with soap and water for at least $15 \mathrm{~min}$. In case of eye contact, flush eyes with water. Consult a doctor if necessary. Due to lead toxicity and the use of hot plate, it is recommended that students carry out the entire solar cell fabrication in a fume hood.

Sameer Patwardhan*
Duyen H. Cao
Shelby Hatch
Omar K. Farha ${ }^{\dagger}$
Joseph T. Hupp
Mercouri G. Kanatzidis

George C. Schatz*

Argonne-Northwestern Solar Energy Research (ANSER) Center and Department of Chemistry, Northwestern University, Evanston, Illinois 60208-3113, United States

\section{ASSOCIATED CONTENT}

\section{Supporting Information}

A list of the materials used along with the supplier, product number, quantity, and price, details on the synthesis of $\mathrm{CH}_{3} \mathrm{NH}_{3} \mathrm{I}$, and a breakdown of the cost of fabrication of one perovskite solar cell. This material is available free of charge via the Internet at http://pubs.acs.org.

\section{AUTHOR INFORMATION}

\section{Corresponding Authors}

*E-mail: sameer.patwardhan@northwestern.edu (S.P.). *E-mail: schatz@chem.northwestern.edu (G.C.S.).

\section{Notes}

The authors declare no competing financial interest.

${ }^{\dagger}$ O.K.F.: Also at Department of Chemistry, Faculty of Science, King Abdulazizz University, Jeddah, Saudi Arabia.

\section{ACKNOWLEDGMENTS}

This work was supported as part of the ANSER center, an Energy Frontier Research Center funded by the U.S. Department of Energy, Office of Science, Office of Basic Energy Sciences under Award Number DE-SC0001059. We would like to thank Dr. Dmitry Zhdanov of Northwestern University for creating the computer model for the perovskite's crystal structure in the Mathematica program (Figure ${ }^{10}$ ).

\section{REFERENCES}

(1) Reichelstein, S.; Yorston, M. The Prospects for Cost Competitive Solar PV power. Energy Policy 2013, 55, 117-127.

(2) Green, M. A.; Emery, K.; Hishikawa, Y.; Warta, W.; Dunlop, E. D. Solar Cell Efficiency Tables (version 44). Prog. Photovoltaics 2014, 22, 701-710.

(3) Taguchi, M.; Yano, A.; Tohoda, S.; Matsuyama, K.; Nakamura, Y.; Nishiwaki, T.; Fujita, K.; Maruyama, E. 24.7\% Record Efficiency HIT Solar Cell on Thin Silicon Wafer. IEEE J. Photovoltaics 2014, 4, 96-99.

(4) Snaith, H. J. Perovskites: The Emergence of a New Era for LowCost, High-Efficiency Solar Cells. J. Phys. Chem. Lett. 2013, 4, 36233630.

(5) Zhao, Y.; Zhu, K. Solution Chemistry Engineering toward HighEfficiency Perovskite Solar Cells. J. Phys. Chem. Lett. 2014, 5, 41754186.

(6) Kim, H. S.; Lee, C. R.; Im, J. H.; Lee, K. B.; Moehl, T.; Marchioro, A.; Moon, S. J.; Humphry-Baker, R; Yum, J. H.; Moser, J. E.; Gratzel, M.; Park, N. G. Lead Iodide Perovskite Sensitized AllSolid-State Submicron Thin Film Mesoscopic Solar Cell with Efficiency Exceeding 9\%. Sci. Rep. 2012, 2, 591.

(7) Lee, M. M.; Teuscher, J.; Miyasaka, T.; Murakami, T. N.; Snaith, H. J. Efficient Hybrid Solar Cells Based on Meso-Superstructured Organometal Halide Perovskites. Science 2012, 338, 643-647.

(8) Liu, M. Z.; Johnston, M. B.; Snaith, H. J. Efficient Planar Heterojunction Perovskite Solar Cells by Vapour Deposition. Nature 2013, 501, 395-398.

(9) Zhou, H. P.; Chen, Q.; Li, G.; Luo, S.; Song, T. B.; Duan, H. S.; Hong, Z. R.; You, J. B.; Liu, Y. S.; Yang, Y. Interface Engineering of Highly Efficient Perovskite Solar Cells. Science 2014, 345, 542-546.

(10) Chung, I.; Lee, B.; He, J. Q.; Chang, R. P. H.; Kanatzidis, M. G. All-Solid-State Dye-Sensitized Solar Cells with High Efficiency. Nature 2012, 485, 486-489. 
(11) Liu, Y.; Zhao, J.; Li, Z.; Mu, C.; Ma, W.; Hu, H.; Jiang, K.; Lin, H.; Ade, H.; Yan, H. Aggregation and Morphology Control Enables Multiple Cases of High-Efficiency Polymer Solar Cells. Nat. Commun. 2014, 5, 5293.

(12) Yella, A.; Lee, H. W.; Tsao, H. N.; Yi, C. Y.; Chandiran, A. K.; Nazeeruddin, M. K.; Diau, E. W. G.; Yeh, C. Y.; Zakeeruddin, S. M.; Gratzel, M. Porphyrin-Sensitized Solar Cells with Cobalt(II/III)-Based Redox Electrolyte Exceed 12\% Efficiency. Science 2011, 334, 629-634.

(13) Chuang, C. H. M.; Brown, P. R.; Bulovic, V.; Bawendi, M. G. Improved Performance and Stability in Quantum Dot Solar Cells through Band Alignment Engineering. Nat. Mater. 2014, 13, 796-801.

(14) Smestad, G. P.; Gratzel, M. Demonstrating Electron Transfer and Nanotechnology: A Natural Dye-Sensitised Nanocrystalline Energy Converter. J. Chem. Educ. 1998, 75, 752-756.

(15) Smith, Y. R.; Crone, E.; Subramanian, V. A Simple Photocell To Demonstrate Solar Energy Using Benign Household Ingredients. J. Chem. Educ. 2013, 90, 1358-1361.

(16) Boudreau, S. M.; Rauh, R. D.; Boudreau, R. A. A Photoelectrochemical Solar Cell: An Undergraduate Experiment. J. Chem. Educ. 1983, 60, 498-499.

(17) Ball, J. M.; Lee, M. M.; Hey, A.; Snaith, H. J. Low-Temperature Processed Meso-Superstructured to Thin-Film Perovskite Solar Cells. Energy Environ. Sci. 2013, 6, 1739-1743.

(18) Eperon, G. E.; Burlakov, V. M.; Docampo, P.; Goriely, A.; Snaith, H. J. Morphological Control for High Performance, SolutionProcessed Planar Heterojunction Perovskite Solar Cells. Adv. Funct. Mater. 2014, 24, 151-157.

(19) Chavhan, S.; Miguel, O.; Grande, H. J.; Gonzalez-Pedro, V.; Sanchez, R. S.; Barea, E. M.; Mora-Sero, I.; Tena-Zaera, R. OrganoMetal Halide Perovskite-Based Solar Cells with CuSCN as the Inorganic Hole Selective Contact. J. Mater. Chem. A 2014, 2, 1275412760 .

(20) Qin, P.; Tanaka, S.; Ito, S.; Tetreault, N.; Manabe, K.; Nishino, H.; Nazeeruddin, M. K.; Gratzel, M. Inorganic Hole Conductor-Based Lead Halide Perovskite Solar Cells with 12.4\% Conversion Efficiency. Nat. Commun. 2014, 5, 3834.

(21) Hodes, G.; Cahen, D. All-Solid-State, Semiconductor-Sensitized Nanoporous Solar Cells. Acc. Chem. Res. 2012, 45, 705-713.

(22) D’Innocenzo, V.; Grancini, G.; Alcocer, M. J. P.; Kandada, A. R. S.; Stranks, S. D.; Lee, M. M.; Lanzani, G.; Snaith, H. J.; Petrozza, A. Excitons versus Free Charges in Organo-Lead Tri-Halide Perovskites. Nat. Commun. 2014, 5, 3586.

(23) Marchioro, A.; Teuscher, J.; Friedrich, D.; Kunst, M.; van de Krol, R.; Moehl, T.; Gratzel, M.; Moser, J. E. Unravelling the Mechanism of Photoinduced Charge Transfer Processes in Lead Iodide Perovskite Solar Cells. Nat. Photonics 2014, 8, 250-255.

(24) Stranks, S. D.; Eperon, G. E.; Grancini, G.; Menelaou, C.; Alcocer, M. J. P.; Leijtens, T.; Herz, L. M.; Petrozza, A.; Snaith, H. J. Electron-Hole Diffusion Lengths Exceeding 1 Micrometer in an Organometal Trihalide Perovskite Absorber. Science 2013, 342, 341344.

(25) Xing, G. C.; Mathews, N.; Sun, S. Y.; Lim, S. S.; Lam, Y. M.; Gratzel, M.; Mhaisalkar, S.; Sum, T. C. Long-Range Balanced Electronand Hole-Transport Lengths in Organic-Inorganic $\mathrm{CH}_{3} \mathrm{NH}_{3} \mathrm{PbI}_{3}$. Science 2013, 342, 344-347.

(26) Manser, J. S.; Kamat, P. V. Band Filling with Free Charge Carriers in Organonietal Halide Perovskites. Nat. Photonics 2014, 8, 737-743.

(27) Guter, W.; Schone, J.; Philipps, S. P.; Steiner, M.; Siefer, G.; Wekkeli, A.; Welser, E.; Oliva, E.; Bett, A. W.; Dimroth, F. CurrentMatched Triple-Junction Solar Cell Reaching 41.1\% Conversion Efficiency under Concentrated Sunlight. Appl. Phys. Lett. 2009, 94, 223504.

(28) Stamplecoskie, K. G.; Manser, J. S.; Kamat, P. V. Dual Nature of the Excited State in Organic-Inorganic Lead Halide Perovskites. Energy Environ. Science 2014, DOI: 10.1039/c4ee02988g.

(29) Dar, M. I.; Arora, N.; Gao, P.; Ahmad, S.; Grätzel, M.; Nazeeruddin, M. K. Investigation Regarding the Role of Chloride in
Organic-Inorganic Halide Perovskites Obtained from Chloride Containing Crecursors. Nano Lett. 2014, 14, 6991-6996.

(30) Stoumpos, C. C.; Malliakas, C. D.; Kanatzidis, M. G. Semiconducting Tin and Lead Iodide Perovskites with Organic Cations: Phase Transitions, High Mobilities, and Near-Infrared Photoluminescent Properties. Inorg. Chem. 2013, 52, 9019-9038.

(31) Christians, J. A.; Fung, R. C. M.; Kamat, P. V. An Inorganic Hole Conductor for Organo-Lead Halide Perovskite Solar Cells. Improved Hole Conductivity with Copper Iodide. J. Am. Chem. Soc. 2013, 136, 758-764.

(32) Subbiah, A. S.; Halder, A.; Ghosh, S.; Mahuli, N.; Hodes, G.; Sarkar, S. K. Inorganic Hole Conducting Layers for Perovskite-Based Solar Cells. J. Phys. Chem. Lett. 2014, 5, 1748-1753.

(33) Patrick, L. Lead Toxicity, a Review of the Literature. Part 1: Exposure, Evaluation, and Treatment. Altern. Med. Rev. 2006, 11, 222. 